Jnl of Ecclesiastical History, Vol. 7I, No. 4, October 2020. (C) The Author(s), 2020.

Published by Cambridge University Press. This is an Open Access article, distributed under the terms of the Creative Commons Attribution licence (http://creativecommons.org/licenses/by/4.o/), which permits unrestricted re-use, distribution, and reproduction in any medium, provided the original work is properly cited.

doi:10.1017/SoO22046920000081

\title{
The Church of England Advisory Council of Empire Settlement and Post-War Child Migration to Australia
}

\author{
by GORDON LYNCH \\ University of Kent \\ E-mail: G.Lynch@kent.ac.uk
}

Between 1947 and 1965, 408 British children were sent to Australia under the auspices of the Church of England Advisory Council of Empire Settlement and its successor bodies. Situating this work in wider policy contexts, this article examines how the council involved itself in this work with support from some senior clergy and laity despite being poorly resourced to do so. Noting the council's failure to maintain standards expected of this work by the Home Office and child-care professionals, the article considers factors underlying this which both reflected wider tensions over child migration in the post-war period as well as those specific to the council.

B etween 1947 and 1965,408 children were sent to Australia unaccompanied by their parents under the auspices of the Church of England Advisory Council of Empire Settlement and its successor bodies. ${ }^{1}$ One of eight voluntary organisations approved by the United Kingdom government to undertake child migration work with

$\mathrm{CRC}=$ Church of England Record Centre, London; LPL = Lambeth Palace Library, London; NAA = National Archives of Australia, Canberra; NLA = National Library of Australia, Canberra; TNA = The National Archives

${ }^{1}$ In the period covered by this article the name of the Church of England Council of Empire Settlement changed to the Church of England Advisory Council of Empire Settlement in 1937, to the Church of England Council for Commonwealth and Empire Settlement in 1955 and then to the Church of England Council for Commonwealth Settlement in 1958. The council was then reconstituted in $197^{2}$ as a committee operating under the Board of Social Responsibility. The decision to begin child migration work, and most of its child migration activities, took place whilst the organisation was constituted as the Advisory Council, but over a hundred children were also migrated in its later organisational forms and this continued until the mid-196os. 
financial support provided through the 1922 Empire Settlement Act and subsequent iterations of this legislation, the council was responsible for the migration of around 12 per cent of all post-war unaccompanied British child migrants to Australia. ${ }^{2}$

The child migration work of the council, and indeed the council's work more generally, has previously received relatively little scholarly attention. Historical research on post-war child migration to Australia has focused more on government policy processes or on the work of other voluntary organisations involved in the delivery of these schemes. ${ }^{3}$ Whilst the work of the council has received some attention in the eight previous public investigations into the abuse and neglect of former British child migrants, both these investigations and public representations of the history of postwar child migration more generally have tended to focus more on the Fairbridge Society and Catholic organisations.4 Drawing on archival records for the council held by the Church of England Record Centre and Lambeth Palace Library, as well as other relevant archival and oral history material in the UK and Australian National Archives and National Library of Australia, this article addresses this gap by examining both the policy context within which the council undertook this work, its relationship with the wider Church and the nature and implications of its working practices.

${ }^{2}$ Stephen Constantine, 'The British government, child welfare, and child migration to Australia after 1945', Journal of Imperial and Commonwealth History xxx/1 (2002), 99132.

3 See, for example, Barry Coldrey, "AA charity which has outlived its usefulness": the last phase of Catholic child migration, 1947-56', History of Education xxv/4 (1996), 373-86; Geoffrey Sherington and Chris Jeffrey, Fairbridge: empire and child migration, Nedlands, WA 1998; Constantine, 'The British government', 99-132; Julie Grier 'Voluntary rights and statutory wrongs: the case of child migration, $194^{8}-76$ ', History of Education xxxi/3 (2002), 263-80; and Ellen Boucher, Empire's children: child emigration, welfare and the decline of the British world, I869-1967, Cambridge 2014. On earlier moral framing of some of these schemes see also Shurlee Swain and Margaret Hillel, Child, nation, race and empire: child rescue discourse, England, Canada and Australia, I850-I9I5, Manchester 2010.

4 See Legislative Assembly, Western Australia, Select Committee into Child Migration, Interim report, Perth 1996; UK Parliament Health Committee, Third Report, The welfare of former British child migrants, London 1998; Preliminary report on Neerkol for the Commission of Inquiry into Abuse of Children in Queensland Institutions, Brisbane 1998; Report of the Commission of Inquiry into Abuse of Children in Queensland Institutions, Brisbane 1999 (Forde Report); Australian Senate Community Affairs Committee, Lost innocents: righting the record: report on child migration, Canberra 2001; Historical Institutional Abuse Inquiry, Report of the Historical Institutional Abuse Inquiry, module 2, Belfast 2017; Australian Royal Commission, Case studies 5 (on Salvation Army institutions in Queensland and New South Wales), I I (on Christian Brothers institutions in Western Australia) and 26 (on St Joseph's Orphanage, Neerkol), Canberra 2018; and Independent Inquiry into Child Sexual Abuse, Child migration programmes investigation report, London 2018. 
Whilst this article adds to our understanding of migration work undertaken by the Anglican Church in a comparatively under-researched period in the historiography of the Church and imperial migration, 5 its primary focus is on understanding the context and reasons for the council's failure to adhere to standards for child migration expected by the Home Office and other child-care professionals. Post-war child migration operated in the wider context of a major reframing of the policy and public governance of children's out-of-home care, shaped both by the influential Curtis report and the 1948 Children Act. In this wider context, new expectations were developed both about the working methods of voluntary organisations in the United Kingdom responsible for sending child migrants overseas and for the standards of care that they would receive in the institutions to which they were sent. ${ }^{6}$ As other studies have noted, a number of voluntary organisations failed to adhere to these standards in a wider context of policy failure by Australian Commonwealth and state governments, and United Kingdom government departments, to maintain effective systems of regulation and oversight. 7 Whilst these failures by voluntary organisations might be perceived more generally in terms of tensions between state and the voluntary sector in the emerging post-war welfare state, the causes of these failures were grounded in structural and cultural factors specific to each organisation. In examining factors which led to failures in the council's work, this article therefore seeks to contribute to a more nuanced, critical history of post-war child migration that situates the failure to safeguard child

5 On the historiography of the involvement of the Anglican Church in imperial migration in earlier periods see, for example, Hilary Carey, God's empire: religion and colonialism in the British world, c. I80I-I9o8, Cambridge 2011; Joseph Hardwick, An Anglican British world: the Church of England and the expansion of the settler empire, c. I790-I86o, Manchester 2014; Rowan Strong (ed.), The Oxford history of Anglicanism, III: Partisan Anglicanism and its global expansion, I829-c. 1914, Oxford 2017; Rowan Strong, Victorian Christianity and emigrant voyages to the British colonies c. I840-c. I9I4, Oxford 2017; and Michael Snape, 'Anglicanism and interventionism: Bishop Brent, the United States and the British empire in the First World War', this Journal lxix (2018), 300-25. On the changing post-war context for Commonwealth ties and migration see, for example, Boucher, Empire's children, and Sarah Stockwell, The British end of the end of empire, Cambridge 2018.

${ }^{6}$ Post-war child migrants sent overseas through funding agreements made under the Empire Settlement Act were sent to residential institutions in Australia, Canada and Southern Rhodesia, with only a small number placed directly or subsequently in family homes for adoption or fostering. A short-lived scheme to New Zealand, funded by the New Zealand government, which placed children directly in fostercare was not a subject of policy discussions within the United Kingdom government as it played no formal role in the funding or regulation of this scheme.

7 On this, see, for example, Constantine, 'The British government', and Gordon Lynch, Remembering child migration: faith, nation-building and the wounds of charity, London 2015 . 
migrants in the meso-level structures and cultures of individual voluntary organisations alongside the macro-level failures of government policy and regulation. ${ }^{8}$ With issues of safeguarding failures in religious organisations also receiving significant public attention through the recent work of the Royal Commission into Institutional Responses to Child Sexual Abuse in Australia and the Independent Inquiry into Child Sexual Abuse in England and Wales, this article also provides an historical case study of how the complex structures of the Church of England led to failures in the governance and oversight of the council's work with children.

To set the council's post-war child migration activities in context, this article begins by discussing its formation in 1925 in the wake of more ambitious government policies for encouraging imperial migration. The rapid rise in the council's assisted migration activities, followed by an equally dramatic decline in the face of global economic depression, led to a re-framing of the council's aims and the scope of its work during the mid-193os. Despite being reconstituted primarily as an advisory body through that process, this article goes on to consider how the council quickly sought to involve itself again in administering assisted migration. As part of its renewed work in assisted migration, in the post-war period the council began for the first time to arrange for the migration of children to residential homes run by Anglican and other Protestant organisations in Australia. This work was undertaken in the context of continued significant financial pressures on the council's work, as well as growing resistance to it within the Church, and with its child migration activities largely undertaken by a solitary administrator with no significant oversight of her work. The article goes on to consider how the council's child migration work took place in the context of broader post-war policy discussions about child migration and discusses how, by 1957, its activities had come to be regarded with significant concern by the Home Office. The article concludes both by comparing the nature of the council's child migration work with that of other voluntary organisations at that time, arguing that its failures to maintain appropriate child-care standards of that time reflected not simply a conflict between voluntarism and the increasing professionalisation of children's out-of-home care or between supporters of imperial migration and of progressive approaches to child-care, but the particular nature of the council's governance, structures and culture as a body operating at that time within the Church of England.9

${ }^{8}$ On a comparable study of such organisational failings in the context of post-war Catholic child migration see Gordon Lynch, 'Catholic child migration schemes from the United Kingdom to Australia: systemic failures and religious legitimation', Journal of Religious History, forthcoming.

9 This study should therefore be understood as working within the history of childhood, in that its focus is on organisational structures and working practices in relation 


\section{The formation of the Church of England Council of Empire Settlement}

In 1917 the Dominions Royal Commission concluded its five-year review of how the natural, human and economic resources of Britain and its five selfgoverning overseas Dominions could be most effectively managed. In its final report, the commission argued that there was considerable scope for far more effective use of these human resources through better co-ordinated and funded schemes of assisted migration to the Dominions which could support their economic development and thus strengthen trade between these constituent parts of the empire. ${ }^{10}$ Noting that the "youth and adaptability' of child and juvenile migrants made them the most advantageous recipients of funding for assisted migration, its report echoed the sentiments of later post-war advocates of child migration in regretting that more children in the care of the state had not been made available for this purpose. ${ }^{11}$

In response to the commission's recommendations, the Oversea Settlement Committee was established as part of the administrative responsibilities of the Dominions Office to develop and fund more effective assisted migration policies. Under the committee's auspices discussions began with the Dominion governments of Canada, Australia and New Zealand about the development of more ambitious assisted migration schemes with substantial financial support from the United Kingdom government. ${ }^{12}$ Ratified by the 1921 Prime Ministers' Conference, ${ }^{13}$ this agreement was enacted into law through the 1922 Empire Settlement Act which enabled the Secretary of State for Dominion Affairs to authorise government funding for up to half of the costs of any agreed scheme for assisted

to children, rather than as a children's history primarily concerned with the lived experiences of children sent overseas through the council's work. For accounts of the experiences of child migrants sent to Anglican children's homes in Australia see, for example, Margaret Humphreys, Empty cradles, London 1994, 15-18, 47-52, $173^{-}$ 83, and also interview with Ken Pound, 'Forgotten Australians and Former Child Migrants Oral History Project', NLA, nla.obj-219399697. On eight accounts of sexual abuse at Anglican children's homes in Australia see Independent Inquiry into Child Sexual Abuse, Child Migration Programmes Investigation Report, London 201 8, 120.

${ }^{10}$ Final report of the Royal Commission on the natural resources, trade and legislation of certain portions of his majesty's dominions, cmd.8462, London 1917.

${ }^{11}$ Ibid. paras $483^{-} 5^{\text {o8. }}$.

12 Conference of prime ministers and representatives of the United Kingdom, the Dominions and India, held in June, July and August, I 92 I: summary of proceedings and documents, cmd.1474, London $1921,59-63$.

${ }^{13}$ Ibid. 8-9. Given that this agreement focused on the use of migration to encourage primary production in the Dominions, the South African government indicated that the lack of need for white labour in South Africa meant that it was unlikely to participate in this arrangement in this form which seemed more suited to the needs of Australia, New Zealand and Canada. 
migration to the Dominions, subject to agreement from the Treasury. Government expenditure under these provisions was allowed to rise in following years up to $£_{3}$ million per annum, with this legislation subject to renewal every fifteen years.

In the context of these more ambitious plans and financial support for migration to the Dominions, new opportunities arose for voluntary organisations to act as bodies which could undertake the administrative work to develop specific migration schemes and receive and disburse Empire Settlement Act funding. Both the Oversea Settlement Committee and Dominion governments recognised that the potential financial resources made available by the act were only likely to be drawn on sufficiently if there was more effective collaboration between organisations in the Dominions which could raise group nominations for immigrants based on local opportunities and support immigrants on arrival, and organisations in the United Kingdom which could publicise these opportunities and put forward migrants to fill them. Religious organisations were an obvious means of such trans-national co-operation, and in 1925 the Church Assembly of the Church of England responded to invitations from the Dominions Governments to engage in this work by establishing the Church of England Council of Empire Settlement, formed under the presidency of the archbishop of Canterbury and the chairmanship of Lord Jellicoe, the Admiral of the Fleet. ${ }^{14}$

With its creation publicly welcomed by both King George $v$ and the secretary of state for Dominion Affairs, Leo Amery, ${ }^{15}$ an early task for the council was to ensure that appropriate overseas partners were identified with whom it could collaborate. In Australia, working relationships were established with diocesan organisations across most Australian states, such as the Church of England Immigration Council in Queensland which received financial support both from the Australian Commonwealth Government as well as from the Church of England Council of Empire Settlement. ${ }^{16}$ Agreement to support the council's work was also obtained from other organisations associated with the Church, such as the SPCK, the Society for the Propagation of the Gospel, the Waifs and Strays Society and the Church Army, which not only publicised the council's work but in some cases also passed on a number of people for whom assisted migration arrangements were

${ }^{14}$ Report of the Church of England Council for Empire Settlement for the nine months ending 3 Ist December 1925, and Second annual report for the Church of England Council for Empire Settlement for the year ending 3 Ist March 192 7, CRC, CECES-2.

16 See, for examples, documents and correspondence at NAA, CP21 1.2.3.104. On contact with overseas committees organised by archbishops or bishops in their respective states see also memorandum on Church of England Advisory Council of Empire Settlement, TNA, n.d., MH102/1888. 
made. ${ }^{17}$ By 1927 the growing numbers of applicants for assisted migration being helped through the council's office had led the Dominions Office to award a recurrent grant-in-aid towards its administrative costs. During the following year this was extended to grants made payable by the Dominions Office to support the work of the council's partner organisations overseas with more than 70 per cent of the council's income now coming from Empire Settlement Act funding. ${ }^{18}$ Whilst the numbers being migrated through the council-2,563 in 1927 and 2,362 in 1928 - remained relatively modest in the context of the national average of between 30,000 and 70,000 assisted migrants per annum during the 1920 , the council consoled itself that its contribution to empire settlement extended beyond this to publicising opportunities for migration to the Dominions that some might eventually take up through other migration agencies. ${ }^{19}$ Reflecting the strong support for juvenile migration in reports by recent Oversea Settlement Committee delegations to Australia and Canada, ${ }^{20}$ the council also actively encouraged juvenile migration (i.e. the migration of teenagers over school-leaving age) for work placements, usually in agriculture or domestic service.

By 1931, however, the global economic depression was significantly curtailing assisted migration. Rising unemployment and a slump in the market for agricultural products led Dominion governments to take a far less supportive view of assisted migration from the United Kingdom. As the introduction of British immigrants competing with the existing under-utilised labour force became increasingly politically sensitive, Dominion governments began introducing more stringent immigration controls and significantly scaling back or ending their financial support for assisted migration. ${ }^{21}$ The United Kingdom government followed suit,

${ }^{17}$ In the post-war period, the Waifs and Strays Society (now the Church of England Children's Society) did not migrate children exclusively through the council, but also used other recognised sending organisations such as the Northcote Trust: TNA, $\mathrm{MH}_{102 / 1593 .}$

${ }_{18}$ Third annual report of the Church of England Council of Empire Settlement for the year ending 3 Ist March I928, CRC, CECES-2.

19 Fourth annual report of the Church of England Council of Empire Settlement for the year ending 3 Ist March 1929, ibid. For statistics on annual rates of assisted migration after the passing of the Empire Settlement Act see Report to the secretary of state for Dominion Affairs of the inter-departmental committee on migration policy, cmd.4689, London 1934, 6.

${ }^{20}$ British Oversea Settlement Delegation to Australia, Report to the president of the Oversea Settlement Committee from the delegation appointed to enquire into conditions affecting British settlers in Australia, cmd.2132, London 1924; British Oversea Delegation to Canada, Report to the secretary of state for the colonies, president of the Oversea Settlement Committee, from the delegation appointed to obtain information regarding the system of child migration and settlement in Canada, cmd.2285, London 1924.

${ }_{21}$ Report of the Oversea Settlement Committee for the period Ist April I93 I to 3 Ist March I932, cmd.4143, London 1932. 
and by 1933 only 196 people sailed from the United Kingdom on assisted passages funded through the Empire Settlement Act.

The dramatic contraction in assisted migration was to have a significant effect on the council's work. Its sixth annual report, in 1931, began by observing that "never in the history of Empire Settlement has the opportunity and prospects for the time being been worse' ${ }^{22}$ Despite a positive resolution about the value of imperial migration being passed at a meeting of bishops convened by the council alongside the 1930 Lambeth conference, not only were prospects for further migration substantially limited by the economic downturn, but a number of those migrated by the council were now facing significant challenges through unemployment or reduced wages, with some juvenile migrants placed on farms now having to work for board and lodging only. Whilst emphasising the practical support that had been offered to them through its overseas partners, the council also sought to avoid being held responsible for these difficulties, stating that it merely sought to provide information and help those who had made their own decision to migrate. In its seventh annual report, in 1932 , it recorded that its core administrative funding from the Dominions Office had now been completely withdrawn, along with that for all other voluntary organisations undertaking similar work. ${ }^{23}$ The council continued to make unsuccessful representations to the Dominions Office $r e$ restoring its grant-in-aid, with its annual report recording that 'it was at one with all those people in the Empire who believe that future Empire Settlement can alone maintain in full vigour the bond of the Empire, or keep the new countries refreshed with the blood of the old'. With the council's administrative work in arranging any further assisted migration having ground to a halt, and questions raised about the rationale for its continued existence, its remaining staff became more preoccupied with welfare issues concerning the 5 ,ooo people-including around 2,000 juvenile migrants-who had previously migrated under its auspices. ${ }^{24}$

The crisis led to the council commissioning a review of its past work and future role. In a report submitting this review to the Church Assembly, the new chair of the council, Sir Wyndham Deedes, gave the council's full support to the review's main recommendation that it be dissolved in its current form, and re-constituted as an advisory body with a chair appointed

${ }^{22}$ Sixth annual report of the Church of England Council of Empire Settlement for the year ending 3 Ist March I93 I, CRC, CECES-2.

23 Seventh annual report of the Church of England Council of Empire Settlement for the year ending 3 Ist March 1932, ibid.

${ }^{24}$ Eighth annual report of the Church of England Council of Empire Settlement for the year ending 3 Ist March 1933, ibid. 
by the archbishops of Canterbury and York. ${ }^{25}$ Rather than having any ongoing involvement in receiving and publicising group nominations from overseas partners, selecting applicants for these nominations and making arrangements for the funding of passages and emigrants' reception overseas, the newly reconstituted body would focus instead on gathering and sharing information between church and government bodies in relation to empire settlement, and to 'advise the Church Assembly how the energies of the Church might most usefully be aroused and directed to organise successful settlement overseas'. In 1937 this recommendation was implemented and the council was replaced with a new body, The Church of England Advisory Council of Empire Settlement, chaired by the former governorgeneral of Canada, Vere Ponsonby, 9th earl of Bessborough. ${ }^{26}$ Other members of the revised council included the former bishop of Bathurst in Australia, Horace Crotty, the Conservative MPs, Peter Agnew, Sir Edward Grigg and William Wakefield, and the Labour MP, Tom Smith. Another initial appointment was Margaret Bondfield, the former Labour Cabinet Minister and trade unionist who had led the 1924 Oversea Settlement Committee delegation which had recommended ending UK government support for the migration of children under school-leaving age to private households in Canada. ${ }^{27}$ An executive committee made up of representatives of church and other organisations with an interest in emigration was also formed.

Within a year of its formation, however, government support for assisted migration to Australia resumed, and despite its reconstitution as a primarily advisory body, the advisory council quickly became involved again in supporting group nominations from its Australian partners and recruiting and selecting migrants to fill these. Numerous approaches continued to be made to the Dominions Office for the restoration of government funding to support its core administrative activities. These were initially delayed by the United Kingdom government's suspension and review of its assisted migration policies during the war, and then ultimately refused on grounds of insufficient economic resources. ${ }^{28}$ Despite the limited time during which the advisory council was able to resume its direct involvement in arranging assisted migrations before the onset of war, this willingness on its part to move beyond its formal advisory brief was to provide the

\footnotetext{
${ }^{25}$ Report of the Church of England Council of Empire Settlement, London 1936, ibid. $\mathrm{CA}_{5} 47$.

6 Report of the Church of England Advisory Council of Empire Settlement for the year Ist September 1937 to 3 Ist August 1938, ibid. CA618.

${ }_{27}$ Report to the Secretary of State for the Colonies, President of the Oversea Settlement Committee, from the Delegation Appointed to obtain information regarding the System of Child Migration and Settlement in Canada, British Oversea Delegation to Canada, cmd.2285, London 1924.

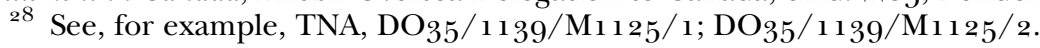


organisational context in which it became involved in child migration in the post-war period.

\section{The council and post-war child migration}

Post-war assisted migration to Australia took place in the context of a substantial review by the Australian Commonwealth government of its immigration policy. Both awareness of the difficulty of defending the vast Australian land mass with a comparatively limited population and demographic trends that seemed to challenge the country's viability in coming decades led to more ambitious plans to increase the Australian population through immigration. A new national department of immigration was created with the senior Labor politician, Arthur Calwell, its first minister. Although some Commonwealth government funding had been provided to support child migration in the pre-war period, new proposals were developed to try to attract 50,000 child migrants from the United Kingdom and continental Europe in the years immediately after the war with plans drawn up to place them in government-run homes and hostels in urban areas. The prohibitive costs of this proposed scheme, as well as challenges in recruiting numbers of children on that scale, meant that it was suspended and replaced by the pre-war policy of funding children to be placed in institutions run by voluntary organisations. Child migration remained a high priority for Calwell's department, however, with children seen as being more adaptable and posing less immediate challenges in terms of employment and housing than adult migrants as Australian society adjusted to demobilisation and the shift from a wartime economy. ${ }^{29}$

As voluntary organisations in Australia began to adapt to the Commonwealth government's more ambitious aims for child migration, so the advisory council also began to contemplate the inclusion of child migration within its wider portfolio of assisted migration work. $3^{\circ}$ With agreements for post-war assisted migration coming into effect between the Australian Commonwealth and United Kingdom governments in 1947, the advisory council began to resume its work. One of its first activities was to support a request for child migrants from the Committee for

${ }^{29}$ See A. R. Peters, memorandum, 29 Nov. 1943, NAA, A441, 1952/13/2684; Nutt to acting secretary, Department of the Interior, with enclosures, 8 Aug. 1945, NAA, A446, 1960/66716; Arthur Calwell, How many Australians tomorrow?, Melbourne 1945; 'Migration to Australia-New Minister Explains Government Plans', 2 Aug. 1945, TNA, DO $35 / 1135 / \mathrm{M} 822 / 29 / 1$; Inter-Departmental Committee on Migration, 10 Sept. 1946, NAA, A446, 1960/66717.

$3^{\circ}$ Lord Bessborough to C. Addison, 23 Nov. 1946, TNA, DO35/1139/M1 $125 / 2$. 
Anglican Orphanages for the Diocese of Perth. ${ }^{31}$ Although an initial nomination had been submitted for fifty children to be sent to the Anglican Swan Homes in Perth, consultation between state officials and the Homes' manager confirmed that, on the basis of the available accommodation, this should be reduced to twenty boys between the ages of ten and twelve. $3^{2}$

A lack of records makes it difficult to establish exactly how the advisory council went about identifying and selecting children to be put forward for these nominations. Information given to the Home Office about the council's child migration work in 1949 by its secretary, Enid Jones, was also vague on this. 33 Some children seem to have been referred through church organisations associated with its work, including what had by then become the Church of England Children's Society, some from local authority care and some referred on by the Law Society. 34 There is also evidence, in 1947, that the advisory council approached London County Council with a view to the possible migration of children under their care through the Poor Law and that for at least part of the early post-war period it relied on other local authorities for identifying possible child migrants. 35 The degree of interest from local authorities, mindful of a duty of care that had been consolidated in the 1948 Children Act, was regarded as 'poor' by the council with only two local authorities putting children forward for migration under the council's auspices by the autumn of $1949.3^{6}$ With at least some of these children still living with their families rather than in residential institutions, the advisory council noted from the outset that 'recruiting suitable children under this scheme presents great difficulties, especially as there appears to be some reluctance on the part of parents or guardians to allow children to travel such a long distance'.37 Although this practice became more common with some other child migration organisations in Britain from the mid$195^{\circ}$, it appears that from a fairly early stage the advisory council sent a number of children whose parents were to follow them to Australia at a

$3^{11}$ See correspondence and documents in TNA, $\mathrm{DO}_{35} / 3388$, and NAA, K403, $\mathrm{W}_{59} / 114$.

${ }_{32}^{2}$ Walter Garnett to C. W. Dixon, with enclosure, 12 June 1947, TNA, DO35/3386.

33 Church of England Advisory Council of Empire Settlement Scheme, memorandum from meeting on 21 Feb. 1949, TNA, MH102/1888.

34 On how children were referred to the council see speech by Bell in Church Assembly: report of proceedings, xxxiv, 34, 1954, spring session, p. 9o, CRC.

35 G. A. N. Lowndes to secretary of state for Home Affairs, 9 July 1947; R. L. Dixon note, 6 Aug. 1947, TNA, DO $35 / 3389$; memorandum on the Church of England Advisory Council of Empire Settlement, n.d., TNA, MH102/1888.

${ }^{36}$ Enid Jones to Noel Lamidey, 26 Sept. 1949, NAA, A436, 1949/5/6347.

37 Report of the Church of England Advisory Council of Empire Settlement for the year Ist January 1947 to 3 Ist December I947, CRC, CECES-2-CA897, 3. 
later stage and who might take them out of residential care when family circumstances allowed. $3^{8}$

The migration of sixteen children to the Swan Homes under this nomination during the autumn of 1947 revealed both flaws within the advisory council's own systems as well as poor oversight of the placement of children sent to Western Australia under both Anglican and Catholic schemes by the UK High Commission in Canberra. In its annual report for 1947, the advisory council noted that a nomination for twenty-five children for the Swan Homes had been accepted by Australian immigration officials, and that its contacts in Western Australia had sent a 'very cheerful account' of the child migrants who arrived at the Swan Homes that autumn. 39 In reality, though, only a maximum of twenty boys were meant to be sent under this nomination with this having been reduced from an original request for fifty children. $4^{\circ}$ The advisory council included six girls in the second party of child migrants that it sent to the Swan Homes that autumn despite the fact that a report by state officials earlier in the year had indicated that no accommodation was available for girls. Before their sailing the advisory council appear to have insisted to immigration officials at Australia House that no reduction had been made to the original requested numbers and that there had been no restriction on the migration of girls, with Australia House only apparently later checking this with the Commonwealth Department of Immigration which informed them that the advisory council was wrong..$^{1}$ This failure to observe the agreed terms of the group nomination was noticed by Walter Garnett, the Official Secretary of the UK High Commissioner, the following year, who asked the Commonwealth Department of Immigration why these girls had been included in breach of this agreement. $4^{2}$ No response to this query from Commonwealth or state immigration officials is recorded on file. This was not an exceptional case, however. Fifty-two Roman Catholic girls had

$3^{8}$ See, for example, confidential appendix on Swan Homes, Perth: TNA, BN29/ 1325. See also correspondence at NAA, $\mathrm{K}_{403}, \mathrm{~W}_{59} / 1_{14}$, and Jones to Lamidey 26 Sept. 1949, NAA, A436, 1949/5/6347. Although the council appeared to have accepted parental assurances that they were planning to migrate to Australia in the future and would reunite with their families, the UK government's $195^{6}$ fact-finding mission noted the emotional disruption caused for child migrants who were migrated to Australia and admitted to residential institutions without clear plans about when their parents would join them.

39 Report for the year Ist January 1947 to 3 Ist December I947, 3.

$4^{\circ}$ See T. M. Nulty to R. L Dixon, with enclosure, 22 Aug. 1947, TNA, MH102/1556, and $\mathrm{DO}_{35} / 3389$. The limit of 20 boys for this nomination is repeated through other Commonwealth Relations Office files as well: TNA, DO $35 / 3389$.

$4^{1}$ See Lamidey to Tasman Heyes, 9 Dec. 1947, and Heyes to Lamidey, 3o Dec. 1947 , NAA, K4O3, W59/114.

$4^{2}$ See Garnett to F. H. Ordish, 5 May 1948, NAA, K403, W59/114. See also H. E. Smith to Heyes, 26 May 1947, with enclosures, NAA, A445, 133/2/8. 
been sent to Nazareth House, Geraldton, in the autumn of 1947 despite it not being a receiving institution approved by the United Kingdom government, and the numbers and ages of young Catholic boys sent to the Christian Brothers' residential institution at Castledare that autumn were also in breach of agreed limits. Whilst these failures clearly demonstrated a lack of effective monitoring by the United Kingdom government about the profiles and numbers of children being sent to receiving institutions in Western Australia, the migration of these children in contravention of agreed limits also suggested that immigration officials at Australia House may have been prepared to exercise a certain latitude in order to maintain the numbers of children being sent.

With funding agreements for child migrants' maintenance and outfitting finalised with the Commonwealth Relations Office (formerly the Dominions Office) in October 1948,43 the advisory council's child migration work gradually increased. With only twenty-eight children migrated under its auspices in 1947 and 1948, it arranged the migration of thirtynine children in 1949 and until 1957 (with the exception of a drop in 1951) continued to migrate between thirty-five and fifty children per annum. 44 Group nominations, or 'requisitions', for specific numbers of children (of particular gender and age ranges) for specific receiving institutions in Australia began to be advertised in its annual reports. 45 The archbishop of Canterbury, Geoffrey Fisher, provided a warm endorsement of the council's child migration work in $195^{1}$ based on his recent experience of visiting Australia. He wrote that

Nothing more impressed me than the Swan Homes near Perth ... The accommodation was good, the whole spirit of the Homes most helpful and friendly, the children themselves obviously happy and full of life. The Homes have a lovely situation and the scenery surrounding them is very English, fields with their cows and horses, a stream meandering through them, and hills in the distance which might be the Chilterns. The children were being effectively trained to be good citizens and good Christians. $4^{6}$

Lack of funding from the Commonwealth Relations Office and the Church Assembly continued to create significant financial pressures for the council, however. Further unsuccessful attempts were made by Bessborough to press the Secretary of State for Commonwealth Relations

43 See TNA, DO35/3388.

44 Constantine, 'The British government', 132.

45 See, for example, Report of the Church of England Advisory Council of Empire Settlement for the year Ist January to 3 Ist December 1948, CRC, CECES-2-CA935.

${ }_{4}^{6}$ See notes 2, 11 Mar. $195^{1}$, Geoffrey Fisher papers, LPL, MS 84 , fos 307-9. This commendation was reprinted in the council's annual report that year: Report of the Church of England Advisory Council of Empire Settlement, for the year Ist January I950 to 3 Ist December I95o, NAA, A436, 1949/5/6347. 
to restore the advisory council's grant-in-aid, 47 after which Bessborough and Fisher sought to increase voluntary subscriptions to it through a letter in The Times which foregrounded its child migration activities as exemplifying the good work that it was undertaking. ${ }^{8}$ When this appeal failed to generate sufficient funds, Bessborough and Fisher made a fresh attempt to have government funding restored in $195^{2}$, noting the valuable work that was done both in arranging the migration of children and managing the pastoral care of adult migrants despite only having two paid staff. 49 A private briefing note advising on the response to this by a Commonwealth Relations Office civil servant noted that, under continued difficult economic circumstances, the trend was towards ending rather than renewing such funding. The advisory council's migration work was described as 'useful but modest', capable of being taken over by other organisations doing similar work and the advisory council was seen as 'hardly indispensable'. $5^{\circ}$ A more carefully phrased response from the secretary of state regretting his inability to provide funding under current economic conditions was sent, $5^{1}$ and the advisory council continued to be funded through private subscriptions and bequests.

Shortly after this, the advisory council's precarious financial position led the Church Assembly to pass a motion proposed by the bishop of London, William Wand, to appoint a commission to undertake another review of the Church of England's involvement in supporting migration to the former 'white Dominions' including the advisory council's future role and constitution..$^{2}$ Seconded by George Bell, bishop of Chichester, both bishops argued that there was a need for an active effort to maintain an Anglican presence in overseas Dominions given the Catholic Church's active support for migration, with Wand also noting that the council's child migration work involved sending children to some 'first class' residential homes. Wand lamented the fact that, in his nine years as a member of the Church Assembly, he could not recall any previous discussion of the council's work and that, given the severe pressures under which the

47 See documents and correspondence at TNA, $\mathrm{DO}_{35} / 3389$.

$4^{8}$ 'Empire settlement', The Times, 18 May 1950, held ibid.

49 Bessborough and Fisher to Robert Gascoyne-Cecil, marquess of Salisbury, 2 July $195^{2}$, ibid.

$5^{\circ}$ J. P. Gibson, note, 14 July $195^{2}$, ibid. On the wider context of the growing scepticism within the Commonwealth Relations Office about the economic value of the United Kingdom government's financial contribution to assisted migration to Australia see, for example, TNA, $\mathrm{DO}_{35} / 3424$.

$5^{1}$ Salisbury to Fisher, 18 July 1952, TNA, DO35/3389. Fisher made a further approach to the Commonwealth Relations Office for the restoration of this funding in 1960 and was again turned down: Fisher to Alec Douglas- Home, 14 Mar. 1960, and Sandys to Fisher, 17 Oct. 1960, Fisher papers, Ms 239, fos 259-61.

$5^{2}$ See Church Assembly: report of proceedings, xxii, 1952, autumn session, 260-5, CRC. 
council's limited staff were attempting to maintain its work, more interest needed to be taken by the Church Assembly if it were to survive. Whilst it was not unusual in this period for Church Assembly councils to present their reports without debate at the Church Assembly,53 it was also the case that discussion of international matters in its meeting focused far less on relations with the Dominions and more on issues such as the Cold War, the rise of Communism and the implications of the rise of national independence movements. 54 The commission would therefore provide an opportunity for the Church to reaffirm its commitment to building up the Anglican Communion in the 'white Dominions' through Anglican emigration from the United Kingdom.

Chaired by Sir Gerald Campbell, the former UK High Commissioner to Canada, and with its membership including Wand, George Bell, Bessborough, Sir Harry Batterbee (a former senior civil servant and UK High Commissioner to New Zealand) and the Conservative MP, Enoch Powell, the commission endorsed the critical role that non-governmental bodies including the Church had always played in imperial migration. 55 With the United Kingdom government still cautious in its support for emigration and its involvement focused on practical matters of administration, there would, the commission argued, always remain an important role for the Church in providing the wider forms of pastoral care and support which were necessary for making emigration to Commonwealth countries successful. Furthermore, it claimed, there was often too little appreciation in Britain of the need for maintaining a proper 'religious balance' in Commonwealth countries and, in the face of the obvious commitment of the Catholic Church to supporting emigration, there was an obvious duty for the Church of England to match this in providing migrants for Anglican Churches overseas. $5^{6}$ This included the need to meet the

53 See, for example, Church Assembly: report of proceedings, xxxxi, 1951, summer session, 271 , ibid.

54 See, for example, more extensive debates on reports by the Assembly's Overseas Council and the Council for Ecumenical Cooperation, ibid. spring session, 408-23; xxxiv, 1954, spring session, $38-47$, CRC.

55 Correspondence and documents relating to the creation of the Campbell Commission are held in the George Bell papers, LPL, MS 183, fos 1-53. Its final report was published as Church Assembly, Report of the Empire Settlement Commission, Jan. 1954, CRC, CECES-2-CA1 100.

$5^{6}$ William Wand also made the point about the moral obligation of the Church of England to honour the financial commitment of Anglican dioceses in expanding children's homes to receive child migrants by sending children to fill these vacancies in his speech commending the Campbell Commission to the Church Assembly: Church Assembly: report of proceedings, xxxiv, spring session, 96, CRC. On Roy Peterkin's recollection of pressure from the archbishop of Perth for the Swan Homes to compete with Catholic child migration work see Australian Senate Community Affairs Committee, Lost innocents, para 2.39. On attempts to secure Commonwealth and State 
demands for British children from Anglican children's homes in Australia which 'the Church of England is clearly under an obligation to satisfy' - a remark apparently reflecting evidence received by the commission that the Anglican Church in Australia had spent thousands of pounds expanding their children's homes to make space for British child migrants. 57 Despite the important work previously done by the advisory council, the commission noted that this was too little known within the Church Assembly itself, let alone the wider Church of England, and that it was now essential to formalise the advisory council's role as the Church's official migration body by constituting it as a formal council of the Church Assembly and providing it with sufficient annual funding from the Central Board of Finance to allow the employment of more support staff. As part of these additional resources, for the first time in the existence of the (advisory) council, it was recommended that funding be provided to enable Jones to visit the institutions in Australia to which it was sending child migrants. The ambiguity suggested by the word 'advisory' in the council's name should be dropped, with the newly constituted body to be now known as the Church of England Council for Commonwealth and Empire Settlement.

The positive endorsement of the Advisory Council's work in the Campbell Commission's report obscured a more complex picture, however. In preparation for the Campbell Commission, Geoffrey Fisher appointed a smaller review of the advisory council's work to provide information which could inform the setting up of the larger commission. The confidential report produced by this review was far more critical in its assessment of the relationship between the advisory council and the Church. $5^{8}$ It was clear, it stated, that the advisory council had operated for a number of years almost solely through the work of its secretary, Enid Jones, with its limited financial resources meaning that she was continuing to undertake this work whilst still owed £80o in wages. There was little by way of organisational structures to support her work. The council itself only met annually - with only four or five of its members usually attending even then - and its executive committee, which was meant to have some role in supporting the selection of migrants, had not met

Government funding to expand the Swan Homes to provide additional space to accommodate child migrants see Roy Peterkin to Calwell, 11 Mar. 1948, and Calwell to Peterkin, 1 Apr. 1948, NAA, K403, W59/114. See also previous concerns amongst Protestant Churches in the United Kingdom about more organised Catholic migration schemes, and the suspicion that Catholic organisations received preferential treatment from the Commonwealth Department of Immigration under Calwell: Bessborough to Fisher, 25 June 1947, and Burlingham to Eley, 3 July 1947, Fisher papers, Ms 27, fos 329,333 .

57 Memorandum on the present position, Bell papers, MS 183 , fos $19^{-21}$.

$5^{8}$ Report of the Empire Settlement Commission, 30 Apr. 1953, ibid. fos 7-9. 
since 1939. It was, the review concluded, 'little short of deplorable' that the council's work had relied on Jones's goodwill to such an extent, and without her commitment to this work the Church of England's involvement in supporting assisted migration would have come to a halt. The Church Assembly was clearly at fault, the review stated, for allowing the council to continue with such little financial support, but the council itself also bore responsibility for not presenting its dire financial position strongly enough to the Church Assembly. The advisory council had almost entirely failed in its objective of advising the Church Assembly on how its energies could best be channelled to encourage successful overseas settlement, and by concentrating instead on managing requests for migrants arising from nominations from overseas partners, the advisory council had exceeded its terms of reference. An urgent review of the Church's policy with regard to the advisory council was therefore required.

When presented with a copy of this review, Bessborough strenuously objected to it. Writing to Fisher,59 he agreed that it was deplorable that Jones should have had to continue to work without pay, but pointed out that he had regularly made both Fisher and his predecessor, William Temple, aware of the council's financial difficulties and tried to work with them both in approaching the Commonwealth Relations Office for funding and in mounting public appeals. If there was a fault to be found, it lay with the Church Assembly for failing to provide any core funding. ${ }^{60}$ Bessborough noted that he had even gone to the trouble, during the war years, of appointing Jones as secretary to an educational association that he chaired so that she could have a salary that would enable her to continue work for the council and receive expenses that would contribute towards the council's office costs. The review's criticisms of the council's work failed to take account of the fact that it had provided periodic reports to the Church Assembly and in the absence of any objections being raised, the council could be understood to have received the Assembly's 'tacit approval'. Rather than taking such a negative line, Bessborough retorted, it would be better to recognise that if the council had not undertaken the work it had then 'the whole of Church migration would have come to an end'. After receiving a conciliatory response from Fisher, who declared himself appalled at the lack of support from the Church Assembly and reassured Bessborough that the review's comments would not be taken any further, Bessborough replied that he was glad that the review's report was 'now buried'. ${ }^{1}$

59 Bessborough to Fisher, 12 May 1953, ibid. fos $11-13$.

6o This point was further expanded on in Bessborough, chairman of the Church of England Advisory Council of Empire Settlement, memorandum, ibid. fos 22-6.

${ }_{61}$ Fisher to Bessborough, 13 May 1953, and Bessborough to Fisher, 19 May 1953 , ibid. fos $16-17$. 
As the review's confidential report had observed, however, Jones had evidently been undertaking the advisory council's child migration work almost entirely by herself with little or no oversight from the advisory council's members. This was confirmed by Jones herself in an initial submission that she made to the Campbell Commission, in which she also noted that there was little privacy in the council's office for interviews with prospective child migrants and their parents. ${ }^{62}$ In a subsequent, longer written submission to the commission, Jones described in more detail the care she took in considering potential child migrants, gathering information on their backgrounds and making decisions based on this, finding escorts for child migrants' sailings and passing on information about children to receiving institutions in Australia. ${ }^{63}$ The commission members appear to have been satisfied with her account and no questions were raised by them about the suitability of an arrangement in which the management of a child migration rested on the work and judgement of one person with no formal child-care training and minimal supervision. As was to become clear later, however, the account that Jones had given of the careful management of this work was not one that was achieved in practice.

The Campbell Commission's recommendations were accepted by the Church Assembly and the council, in its new form, came into being on 1 January 1955, with Bessborough continuing as its chair and George Bell becoming its vice-chair. ${ }^{6}$ Bell's advocacy for the council's work, until his death in 1958, was important both in ensuring the Church Assembly's support for the recommendations of the Campbell Commission and the Assembly's approval of the annual renewal of the council's funding. ${ }^{6} 5$ Bell also privately lobbied Fisher to ensure that the Campbell Commission's recommendations would be implemented, with Fisher assuring him in advance of the Assembly's debate that this would happen. ${ }^{66}$ In speaking in support of the Campbell Commission's recommendations at the Church Assembly, Bell also commented-presumably on the basis of Jones's evidence to the commission-that 'it was only after careful

${ }^{62}$ Empire Settlement Commission meeting, 30 Sept. 1953, appendix II, ibid. fo. 31.

63 Church of England Advisory Council of Empire Settlement, memorandum on present activities of the council, ibid. fos 32-4.

${ }_{4}$ The Church of England Council for Commonwealth and Empire Settlement, report for the fifteen months, Ist January 1955 to 3ist March 1956, CRC, CECES-2-CA1 176.

${ }_{5}$ See, for example, Jones to George Bell, 22 Feb. 1954, Bell papers, MS 183 , fo. 90; Fisher to Home, 23 Jan. 1959, Fisher papers, MS 21 7, fos 279-80; Church Assembly: report of proceedings, xxxiv, 1954, spring session, 87-99; xxxvi, 1956, summer session, 291-2; xxxvii, 1957, summer session, 322-4.

66 Bell to Fisher, 26 Feb. 1954, and Fisher to Bell, 4 Mar. 1954, Fisher papers, MS 140 fos 342,344 . Whilst Fisher supported the council's work, he also regarded the Campbell Commission's funding request for it from the Church Assembly as financially challenging: Fisher to Bessborough, 23 Jan. 1954, ibid. fo. 341. 
investigation that ... children were shipped to Australia'. ${ }^{67}$ Bell's support was to prove important as the greater profile given to the council in the Church Assembly through the Campbell Commission appears to have stimulated stronger opposition to it. Despite agreeing a budget for the council's work in 1955 , including funding to enable the appointment of more junior administrative staff to support Jones, the Central Board of Finance subsequently blocked approval for the salary for an assistant for her on the basis that the council wanted to appoint someone with more senior responsibilities than had been agreed with the board. With no progress made in obtaining this approval, by the summer of $195^{6}$, the council had resorted to appointing an assistant to her on an unpaid basis and regarded this obstruction as symptomatic of a wider lack of understanding and sympathy for its work within the Church. ${ }^{68}$ To add to these difficulties, in the summer of $195^{6}$ the Church's Committee on Central Funds produced a report questioning whether there was a strong enough rationale for the council to exist as a separate body and whether it should be amalgamated into a larger Council of Church Relations which would deal with international affairs-a proposal reflecting a wider trend towards the Assembly dealing with reports from fewer councils. ${ }^{69}$ Members of the council strenuously resisted this, and nothing came of these proposals. $7^{\circ}$ In subsequent years, however, doubts continued to be expressed (albeit outside the formal sessions of the Church Assembly) about whether the council's work constituted value for money, whether it undertook work that should properly be done by a government department, whether it acted primarily as a migration agency for people who in practice had little active connection with the Church and whether supporting emigration was a broadly desirable policy. ${ }^{71}$ By $195^{8}$ the Central Board of Finance had made it clear that it was no longer willing to meet the full budget requested by the council. $7^{2}$ For the council's members, such opposition to its work was seen as an irresponsible disregard for the Church's responsibilities for involving itself in overseas settlement in British Dominions. As Jones put it, in a memorandum to council members:

67 Church Assembly: report of proceedings, xxxiv, 1954, spring session, 9o, CRC.

68 The blocking of this appointment led to extensive correspondence held on file at Bell papers, MS 183, fos 148-83, 196-204, $25^{2}$.

69 See minutes of ad hoc meeting of the council, 8 Oct. $195^{6}$, ibid. fos $234^{-5}$.

$7^{\circ}$ See confidential situation report, 25 Oct. $195^{6}$, ibid. fo. 245 .

$7^{11}$ See Bell to Harry Batterbee, 12 July $195^{6}$, ibid. fo. 215 ; Fisher to Williams, 7 Jan. 1959, Fisher papers, MS 21 7, fos 271-2; Hodgins to Fisher, 17 Mar. 1960, Fisher papers, MS $25^{\circ}$, fo. 288 .

$7^{2}$ See Church of England Council for Commonwealth and Empire Settlement, report for the year Ist April I957 to 3 Ist March 1958, CRC, CECES-2-CA1 250, 6. 
[i]f the Council ceases to exist then the Church of England in the Commonwealth will have to be informed that the Church here is no longer interested in helping its own members to go overseas. In other words the Church of England at home is not concerned whether the Church of England survives or not which for Australia would be a great shock at the present time with the Roman Church making a big drive towards making Australia a Roman Catholic country.73

Amongst the criticisms of the council, some disquiet was evidently felt by other members of the Church about the desirability of child migration and one of the council's supporters produced a briefing memorandum in defence of its work asserting that it did not seek to separate children from their parents. 74 Whilst the council's child migration work had previously been presented as one of its major activities, it now insisted that it was a relatively minor part of its overall administrative work, despite the numbers of children being migrated through the council remaining broadly the same.75 Although the council, in its re-constituted form following the Campbell Commission, met on a more regular basis, there was no evidence of scrutiny of Jones's management of its child migration work and, given the difficulties in getting funding for her assistant, no new support created for her to undertake it. The provision of funding from the Central Board of Finance did, however, make it possible for Jones to undertake a visit to New Zealand and Australia between December 1955 and February $195^{6.7^{6}}$ Reporting on her visit, the council noted her meetings with both Commonwealth government immigration officials and church representatives. 77 Concern was expressed by the latter at the comparatively higher rates of Catholic immigration to Australia, with the Australian Catholic population reportedly growing by 10 per cent in the past five years partly as a result of this. The Church of England was said to be 'lagging far behind the highly organised Roman Catholic Church activities in this particular field' and there was a need for a national Anglican immigration organisation to match the work of the national Federal Catholic Immigration Committee which had been formed back in 1947. Jones also reportedly visited all the residential institutions to

73 Secretary's memorandum, 5 Oct. 1956, Bell papers, Ms 183 , fos 229-31.

74 Committee on Commonwealth and Empire Settlement, preliminary note, n.d., Fisher papers MS 21 7, fos 291-2; Bickersteth, memorandum, n.d., Bell papers, MS 183 , fo. 233; Church of England Council for Commonwealth and Empire Settlement, report for the I 5 months Ist January, 1955 to the 3ist March, I956, CRC, CECES-2-CA11 76, 5 .

75 Contrast, for example, confidential report of the Empire Settlement Commission, Bell papers, ms 183 , fo. 18 , with Jones to Bell, 27 Nov. 1956, ibid. fo. 239.

$7^{6}$ See proposal to appoint an assistant secretary, ibid. fos $14^{8-} 5^{1}$.

77 Report for the fifteen months 1 Jan. 1955 to 31 Mar. 1956, CRC, CECES-2CA1 176 . 
which the council had sent child migrants and was said to be 'very satisfied with all she saw'.

The council's child migration work and post-war standards in children's out-ofhome care

Through the 195os the council operated in the context of wider public debates and policy initiatives aimed at safeguarding the welfare of unaccompanied British child migrants. The recommendations of the 1946 Care of Children Committee report (more commonly known as the Curtis Report) played a central role in both restructuring government systems for children's out-of-home care in the emerging post-war welfare state and consolidating support for approaches to child-care which emphasised the importance of the emotional care of the child and offering care in environments as close as possible to the "normal family home'.$^{8}$ In implementing many of its recommendations, the 1948 Children Act also consolidated regulations for children migrated from the care of local authorities, for which the consent of the secretary of state was now required in all cases, and also enabled the secretary of state to introduce regulations for the emigration of children in the care of voluntary organisations.79 The Home Office eventually abandoned its efforts to introduce these regulations in 1954, apparently taking the view that the legal constraints of trying to enforce standards within overseas institutions and organisations receiving child migrants meant that such regulations would have limited practical value. $^{80}$ Regulations were drafted, however. Consultations over the contents of these took place with the main voluntary organisations responsible for migrating British children which, including the advisory council, formed an umbrella organisation, the Council of Voluntary Organisations for Child Emigration (CVOCE) in order to represent their interests against feared tighter regulation. ${ }^{81}$ Although never formally introduced, this drafting and consultation process made it clear that amongst standards of good practice expected by the Home Office - to which the constituent members of the CVOCE officially mostly gave their formal agreement - were requirements for child migrants' selection being undertaken through case committees with a good knowledge of their individual

$7^{8}$ Gordon Lynch, 'Pathways to the 1946 Curtis Report and the post-war reconstruction of children's out-of-home care', Contemporary British History, 27 Apr. 201 9, <https:// doi.org/10.1080/13619462.2019.1609947>.

80 See documents and correspondence at TNA, MH102/2047.

${ }^{81}$ See, for example, D. R. Hall to under-secretary of state, 9 Nov. 1951, TNA, $\mathrm{MH} 102 / 1784$. The minutes of meetings of the Council of Voluntary Organisations for Child Emigration are held in the Fairbridge collection at the University of Liverpool, Special Collections and Archives. 
circumstances including a trained social or child-care worker, adequate preparation of children prior to their migration, sending case histories and medical information about child migrants to receiving institutions and ensuring regular reporting on their welfare and progress once overseas. $^{82}$ It was not clear that the advisory council was necessarily wellplaced to meet these requirements, however. As Tasman Heyes, the secretary of the Australian Commonwealth Department of Immigration, noted when arguing against the United Kingdom government's refusal to approve the Royal Overseas League as a child migration organisation on the grounds of its lack of organisational resources and specialist childcare expertise, such objections could equally be applied to bodies such as the advisory council whose work had received formal government approval. ${ }^{83}$

Other evidence of problems with the management of Anglican child migration also emerged. In 1951, during a semi-official tour of receiving institutions for child migrants in Australia, John Moss discovered that some boys sent to the Swan Homes in Perth had been passed on to the Padbury Farm School at Stoneville, Western Australia, when it was found that the Swan Homes had insufficient accommodation for them on their arrival. ${ }^{84}$ Although Padbury was another Church of England home under the same board of management as the Swan Homes ${ }^{85}$ - partly functioning to provide agricultural produce for consumption at the Swan Homes - it had not been approved as a receiving institution for child migrants by the United Kingdom government. As Moss observed, it would have been unlikely to have been approved based on the conditions he saw there during his visit. Padbury was situated in an isolated rural area and the site was still under development using the labour of the boys who had been placed there. Furthermore, Moss commented, Padbury's primary emphasis on training boys for agricultural work meant that it was not an appropriate place to send boys until they had formed a reasonable idea of the future career that they might want to pursue and he recommended that boys under school-leaving age should not be sent there.$^{86} \mathrm{~A}$ discussion then ensued between the Commonwealth Department of Immigration, Commonwealth Relations Office and Home Office about how best to proceed, which ended with the Home Office choosing not to press its

${ }^{82}$ See, for example, note and memorandum by Home Office, TNA, MH102/1 784 .

83 Heyes to Official Secretary, UK High Commission, 22 July 1953, NAA, A445, 133 / $2 / 106$.

${ }^{8}$ See also (n. 9 above) interview with Ken Pound on his experience of being transferred immediately from the Swan Homes to Padbury.

85 See, for example, Anglican Homes for Children, Western Australia, 8oth annual report, 1948, TNA, MH102/1888.

86 Extract from notes of Mr Moss, n.d., TNA, MH102/189o; report on Padbury's Boys' Farm School, 4 Dec. 1951, NAA, PP6/1, 1949/H/1145. 
concerns about Padbury being approved as a receiving institution for younger children. ${ }^{87}$ When Roy Peterkin, the director of the Swan Homes, was consulted about the Home Office's concerns, he commented that 'a boy's welfare, both educational, social and vocational, as well as his living conditions are all thoroughly safeguarded at Padbury. I have never seen an unhappy boy there'. This view did not accord with experiences later described by a former child migrant sent to Padbury at that time, who recalled it as a place of harsh discipline, physical cruelty and sexual abuse. ${ }^{88}$

In $195^{6}$ it was agreed that a United Kingdom government fact-finding mission should be sent to Australia to investigate conditions for child migrants to inform policy decisions being made about the future of child migration policy alongside the periodic renewal of the Empire Settlement Act. Led by John Ross, the former head of the Home Office Children's Department, the mission produced a report which was critical of a number of aspects of current policy, and advised that in future the migration of all children should be subject to consent from the relevant secretary of state. ${ }^{89}$ The mission's strongest comments were, however, reserved for a series of confidential appendices based on inspections of twenty-six of the residential institutions to which British child migrants had been sent, in which some were identified as unsuitable for receiving any more children and a number of others as failing to achieve standards set out in the Curtis report. $9^{\circ}$ These confidential appendices suggested a number of problems with the council's work.91 Boys had been sent through the council to the Melrose home in Pendle Hill, Sydney, where the fact-finding mission found that the lead staff were untrained and inexperienced and had no appreciation of children's needs. Whilst management and standards at the St John's Church of England Home in Melbourne and the Clarendon Church of England Home in Tasmania was found to be better, complaints were raised by staff about the lack of information provided by the council about children's backgrounds, family histories and reasons for emigration which had left some children

\footnotetext{
87 See Nutt to UK High Commission, 5 Sept. 1952; P. L. Taylor to R. L. Dixon, 22 Sept., 1 Oct. 1952, MH102/189o. $\quad{ }_{88}$ See Ken Pound interview (n. 9 above).

${ }^{89}$ Child migration to Australia: report of a fact-finding mission, cmd.9832, London $195^{6 .}$ Consent would have been required from the Home Secretary for children sent from England and Wales, and the Secretary of State for Scotland for children sent from Scotland. This proposal would have extended the existing requirement of s.17 of the 1948 Children Act for such consent to be given for children migrated from the care of local authorities.

$9^{\circ}$ See documents and correspondence at TNA, BN29/1325.

${ }^{91}$ On the following points see confidential appendices on Melrose, Pendle Hill; St John's Church of England Home, Melbourne; Swan Homes, Perth; Clarendon Church of England Home, Kingston Park: ibid.
} 
confused as to why they had been sent to Australia. $9^{2}$ Whilst some aspects of the Swan Homes in Perth were considered acceptable by the mission, concern was also noted about the emotional disruption caused to children by accommodating them separately by age and gender (regardless of whether they had siblings at the same institution) and rotating children to prevent them becoming too attached to a particular house-motherall things that contradicted the Curtis emphasis on maintaining family bonds, home-like environments and an on-going sense of security of affection from a particular care-giver.

A United Kingdom government inter-departmental committee on migration policy, convened later in $195^{6}$, decided not to support the tighter controls over child migration that had been recommended by Ross, fearing in part a negative reaction to this from both the Australian Commonwealth government and those powerful stakeholders in the United Kingdom, including the council, who were organisationally invested in child migration.93 Instead a system of informal inspection was introduced, tied to the renewal of United Kingdom government maintenance funding for child migrants, in which sending organisations were now expected to co-operate in making their records available to Home Office inspectors. 94 The Home Office inspection of the council's records raised significant concerns. Whilst the Commonwealth Relations Office questioned how these concerns could be raised in a way that would not bolster the council's claim for a re-introduction of a grant-in-aid in order to pay for more staff, the Home Office insisted that the shortcomings identified in the council's work were sufficiently serious for them to need to be addressed if it were to continue to arrange any further migration of children. 95

$9^{2}$ Some boys whom members of the mission met at Melrose were also said to be confused about why they had been sent to Australia. Positive comments were also made in the confidential appendices about Burton Hall Farm School, Tartura, Victoria, where although some criticism was made of selection choices by the council, no concerns were raised about lack of records. In a response to the mission's report, Enid Jones sought to justify the limited case histories sent over with child migrants by the council on the questionable grounds that such histories would inevitably be less detailed for children sent from parental, rather than residential, care: Jones to secretary of state, 26 Oct. 1956 , TNA, $\mathrm{DO}_{35} / 63_{3} 8_{3}$.

93 Report of the inter-departmental committee on migration policy, 1956, TNA, $\mathrm{DO}_{35} / 4881$, paras $57-97$.

94 See E. R. Sudbury circular, 27 Dec. 1956, TNA, DO35/10269.

95 See, for example, Gibson to R. W. Whittick, 27 Nov. 1958 , and Whittick to Gibson, 14 Jan. 1958, TNA, DO $35 / 10268$. On some degree of compliance with expected standards see the council's apparent avoidance of sending siblings to different parts of Australia: Jones to Madeleine, 23 Mar. 1950, NAA, A445, 133/2/10. On an earlier case of Home Office concern about the rigour of its selection processes, see also the earlier case in which the Home Office had intervened to suspend the migration of 
In a letter to Jones in April 1958, the Home Office Children's Department noted that its inspectors had found that she had been undertaking the council's child migration work almost entirely by herself without any support or effective oversight from any other members of the council. $9^{6}$ Full case histories of children being migrated through the council had not been developed, nor sufficient liaison undertaken with other organisations previously involved in their care to establish a full picture about their backgrounds. Where information about children had been obtained by Jones, including through selection interviews, she had tended to commit this to memory rather than to written records. It did not appear that all receiving institutions for children sent by the council were sending regular progress reports on their welfare, and when this did take place these reports seemed to be sent directly to families rather than through the council's offices, making it harder for the council to maintain a sense of standards in receiving institutions or issues that it should bear in mind in future selection of child migrants.97 Although Jones was reportedly now trying to send more information about children sent by the council to receiving institutions - presumably having received the same complaints about this that were heard by the Ross fact-finding mission only a couple of months after her own visit to Australia - this had not generally been the case in the past. The fact that the council assumed no responsibility for the care of children in the United Kingdom even immediately prior to migration meant that it had no means of checking whether a child had changed his or her mind about emigration before being placed on board ship. Similarly escorts on ships arranged by the council did not accompany children to their receiving institutions on arrival in Australia, creating problems with continuity of care. Although not raised by the Home Office inspectors-presumably because Jones had visited receiving institutions for child migrants in Australia relatively recently - the fact that the council had no direct personal experience of these receiving institutions for the first eight years of its post-war child migration work fell short of the Home Office's expectation that voluntary organisations in the United Kingdom would have a

three brothers in a case where the council seemed to have made inadequate enquiries about the consent of both parents to their emigration in a case of contested custody: W. Lyon to G. M. Wansborough-Jones, 2 Dec. 1948, TNA, MH102/1886).

$9^{6}$ On this and the other criticisms see Whittick to Jones, 22 Apr. 1958, TNA, DO $35 /$ 10268.

97 This point about the organisational value of receiving regular reports on child migrants overseas was emphasised in Women's Group on Public Welfare, Child emigration, London 1951, 61, a report with which members of the Council of Voluntary Organisations for Child Emigration would have been familiar. 
liaison officer with direct experience of the residential homes to which children were being sent. $9^{8}$

No response to this letter was received from the council despite numerous requests from the Home Office, and in the following spring the Home Office reportedly wrote directly to Sir Harry Batterbee as the new chair of the council to press for one. 99 In the absence of such a response, the Home Office suggested to the Commonwealth Relations Office that the council might well be in breach of its obligations as an approved sending organisation, and that such approval might in future need to be withdrawn. The council eventually agreed that improvements in its administration of child migration were needed and asked the Home Office to allow them time to rectify this situation through a further public appeal for funds. ${ }^{100}$ After further funds were successfully raised to increase the council's administrative resources, the Home Office undertook a further inspection of its office and in the autumn of 1960 agreed that it be allowed to continue as a recognised child migration organisation. ${ }^{101}$ In the following years, however, the council only arranged for the migration of three more children.

The systemic failures within the council to maintain expected standards in post-war child migration gives further insight into the complex relationship between voluntary organisations and the state in the 'mixed economy' of the post-war welfare state. Post-war child migration operated, more generally, in the context of centralising trends in children's out-of-home care exemplified in the 1948 Children Act. Whilst some welcomed the growing emphasis on care by the state as a step towards better and more consistent standards (as well as a shift from seeing some children as 'charity cases'), others questioned whether this might introduce too much statist control over the work of voluntary organisations and whether those who took care of children as a state-paid job could ever do this as well as those drawn to the work from a strong sense of (often religious) vocation. Such disagreements were-in most cases-restricted to the degree of autonomy that voluntary organisations would have under these new arrangements, however, and the passage of the Children Bill through parliament was marked by substantial political consensus about the need to raise standards of child-care in line with the spirit of the Curtis report. ${ }^{102}$

$9^{8}$ 'Emigration of children who have been deprived of a normal home life', n.d., TNA, MH102/1558; NAA, K403, $\mathrm{W}_{59} / 6_{3}$.

99 Whittick to D. M. Cleary with enclosure, 4 Feb. 1959, TNA, DO35/10268.

100 See Whittick to W. Peters, 20 Apr. 1960, TNA, DO $35 / 10255$.

101 W. Peters note, 8 Sept. 1960, TNA, DO $35 / 10269$.

${ }^{102}$ See, for example, House of Commons debates on Children Bill, Hansard, s.5 cdl, 7 May 1948, and s.5, cdlii, 28 June 1948, and House of Lords debates on Children Bill, Hansard, s.5, cdxlviii, 9 Mar. 1948 and s.5, cdxlix, 13 Apr. 1948. Whilst disagreements were evident within the Church of England as to whether the welfare state was more 
Child migration was, however, an important area of post-war children's welfare provision in which support for Curtis principles diverged as attitudes to child-care came into conflict with well-established sentiments about the importance of Commonwealth migration. Whilst child-care professionals and staff in the Home Office Children's Department insisted that Curtis principles should be the standard against which any programme of child migration should be judged, supporters of voluntary organisations involved in this work argued that emigration was in the better interests of some children and that the work should not be held back by dogmatic adherence to a particular approach to child-care. Enid Jones, who had no training or professional background in child-care, fell into this latter group. ${ }^{103}$

The kind of failures demonstrated by the council in the selection of children, the transfer of records and post-migration monitoring were far from unique. The confidential addenda to the $195^{6}$ fact-finding mission observed similar problems in the work of the Overseas League, the National Children's Home and Catholic sending organisations. However, these failures arose not simply from broader policy disagreements with child-care trends in the emerging welfare state, but from factors specific to individual sending organisations. In the case of Catholic child migration, for example, significant problems arose through the willingness of national Catholic child-care officials to continue to work with Australian Catholic administrators despite their recruiting children directly from residential homes against agreed guidelines as well as from the complex politics of relationships between diocesan officials and the religious orders who ran residential children's homes. ${ }^{104}$ In the case of the Overseas League more comparable to the council-a single, voluntary worker with no specialist child-care training had been given considerable latitude to undertake this work with little evidence of close scrutiny by senior officers in the League. ${ }^{105}$ With the council, however, a number of factors gave rise to these failures which reflected its work as a semi-autonomous body working within the Church of England in that period.

In addition to the financial reasons for the under-resourcing of the council's work - and its impact on the rigour of its child migration work - wider structural factors lent wider public credibility to the council's work even though it functioned with little or no effective governance. The Church's strong social capital and networks meant that the council was always able

generally a support or hindrance to the development of Christian virtues such disagreements were less common in relation to debates about raising standards of child-care: Church Assembly: report of proceedings, xxxi, 1951, spring session, 56-69, CRC.

${ }_{103}$ See, for example, Jones to secretary of state, 26 Oct. $195^{6}$, TNA, DO $35 / 6_{3} 8_{3}$.

104 See Lynch, 'Catholic child migration'.

$10_{5}$ Independent Inquiry into Child Sexual Abuse, Child migration, 109-12. 
to draw on an impressive array of public figures, including former diplomats and senior Dominion administrators, ${ }^{106}$ for its members, in addition to the public support that it received for its work from senior clergy such as Fisher and Bell. Whilst the ability of these senior supporters to influence policy-makers, child-care professionals or public opinion should not be over-estimated, their association with the council nevertheless lent its work a degree of credibility which it would otherwise have lacked, contributing to an environment in which civil servants were reluctant to support the stronger controls over child migration work recommended by the $195^{6}$ fact-finding mission. ${ }^{107}$ However, despite the symbolic value of their involvement, members of the council undertook no close oversight of its child migration or other administrative work. This was further compounded by the limitations of the Church Assembly as a mechanism for scrutinising in any detail the work of bodies reporting to it. In the early $195^{\text {os }}$ around ten councils submitted periodic reports to the Assembly, many of which were received without any debate. The Advisory Council of Empire Settlement was not even a formal body within the Assembly until the recommendations of the Campbell Commission were implemented, and even then the extent of the Assembly's control over its work was primarily only financial, reflecting a wider settlement in which the Assembly agreed with its councils that they should have greater latitude over their work and constitutions in return for the councils agreeing to greater control of their funding by the Central Board of Finance. ${ }^{108}$ There may not have been overwhelming interest or support for the council's work within the Church Assembly, with the short debates about its annual reports from $195^{6}$ onwards usually filled with complimentary speeches from a small group of its supporters. However, there also generally appears to have been insufficient time, information or inclination for Assembly members to scrutinise its child migration work and after the Campbell Commission debate in 1954 no reference to the council's child migration activities was made again in Assembly debates. The spiritual symbolism of the valiant, sacrificial worker also meant that the isolation and under-resourcing of Enid Jones's work could be presented as a display of virtue-with Bell praising her in the Assembly for persisting with her work 'despite handicaps which would have daunted a less courageous woman' 109 - rather than as a source of concern about the vulnerable

${ }^{106}$ See a similar ability to recruit senior figures from the colonial and Dominions services to chair territorial councils of the Assembly's Overseas Council: Church Assembly: report of proceeding, xxxi, $195^{1}$, autumn session, 374, CRC.

${ }_{107}$ See Confidential Report of the Inter-Departmental Committee on Migration Policy, 1956 , TNA, $\mathrm{DO}_{35} / 4881$.

${ }_{108}$ On this settlement see Church Assembly: report of proceedings, xxi, 35-6, CRC.

109 Church Assembly: report of proceedings, xxxiv, spring session, 9o, ibid. 
children about whose lives she was making crucial decisions. The absence of any effective over-arching governance of such semi-autonomous bodies within the Church also meant that even after members of the Church's Moral Welfare Council understood in $195^{6}$ that professional opinion amongst child-care workers had clearly turned against child migration to residential institutions, ${ }^{110}$ the Council for Commonwealth and Empire Settlement was still able to continue to send children overseas.

Whilst the fact that a number of voluntary organisations involved in postwar child migration shared similar failings in their work might imply that this arose from broader conflicts between state and voluntarism in the early post-war period, this article suggests that such failings need to be understood in relation to the specific structures and culture of individual voluntary bodies involved. In the case of the council the organisational factors underlying its failures to safeguard children's welfare reflected particular complexities of the Church of England, a national body which combined perceived moral authority, strong social capital and networks with senior figures in public life and a complex organisational structure which - unlike other organisations such as the Fairbridge Society or Dr Barnardo's Homes - meant that no central governance structures existed to provide oversight of a body like the council. In recent years, the challenges of fragmented governance structures within Churches for safeguarding children have become a central focus of national child abuse inquiries. This article suggests that more contemporary cases may have longer historical antecedents, and that whilst many elements of the council's work were specific to its time, aspects of its failures in a complex religious organisational environment may resonate with challenges still being discussed today.

110 See report by Eve Kennedy, minutes of meeting of Church of England Moral Welfare Council, 7 Nov. 1956, ibid. MWC/Min/M/3. 